\title{
A study on relationship between capital structure and economic value added: Evidence from Tehran Stock Exchange
}

\author{
Mohammad Shameli Shahreza and Hassan Ghodrati*
}

${ }^{a}$ Department of Management and Accounting, Kashan Branch, Islamic Azad University, Kashan, Iran CH R O I C L E A B T RACT

Article history:

Received March 20, 2014

Accepted 10 September 2014

Available online

September 202014

Capital structure

Economic value added

Total asset

Total debt

Total equity

\section{Introduction}

The primary objective of management firms is to maximize firm's value added, which yields to increase in the wealth of the shareholders (Modigliani \& Miller, 1963; Zaima et al., 2005). In this regard, the financial management tasks fall into three categories: investment decisions, financing and division of shares. Financing decisions that ultimately determine the company's financial structure or texture is quite important because such decisions will lead to the achievement of the firm's optimal capital structure (Nikbakht \& Peikani, 2010). If management is able to optimally mix debt and equity, it will be able to minimize the cost of capital and to maximize stock prices, consequently maximizing shareholder wealth, and subsequently the value of the company (Hejazipoor, 2014). Financial managers should consider the internal properties of the firms to make appropriate financial structure to maximize the value of the firms (Hejazipoor, 2014). There is a probability of bankruptcy for firms that are vulnerable to mismanagement of financial resources, even though there are positive benefits. Presently, the financial situation of many Iranian firms is not good and most Iranian firms prefer to

*Corresponding author. Tel: +983155621259

E-mail addresses: dr.ghodrati42@gmail.com (H. Ghodrati)

C 2014 Growing Science Ltd. All rights reserved.

doi: $10.5267 /$ j.ms 1.2014.9.012 
change their capital to other investments so they would not be able to pay their debts, which hurts the economic worth. Economic value is influenced by the company decisions, investment decisions, dividend, and return of capital, financing decisions, and cost of capital. As an internal standard, measuring the investment performance of the firms' success in adding shareholder value is the best possible option. Economic value added shows that firm value depends directly on the performance of management. Failure to use of appropriate metrics to measure the performance and the value of shares of a company may cause the value not to lead to the actual value resulting in damage to a group of buyers taking advantage of the stocks and making profits by another group of buyers (Hejazi \& Hosseini, 2013). Some companies produce a final dividend without regarding their opportunity cost of capital estimate. Economic value added (EVA) and the Theory of the company's value are consistent only by selecting projects with positive net present value increase (Hejazi \& Hosseini, 2013). Most previous studies focused on the EVA, the company's profitability and profitability ratios and yield. However, empirical studies suggest that other factors such as type of industry leverage ratios, capital structure and working capital management on EVA are also important. This study seeks to find the relationship between capital structure and EVA.

\section{Literature Review}

Stewart (1991) ranked six hundred and thirteen thousand top US firms in terms of EVA over the period 1987-1988 and divided them into 25 groups. O'Byrne (1996) studied ten-year information to examine the relationship between value added to net income and market value. His findings showed that the market value of EVA explained about $31 \%$ of variance. Kleiman (1999) studied the relationship between value added and value creation in the company. He limited the scope of his research to firms that actually implemented EVA. His results showed that EVA adopter companies had obtained the excess return compared with their industry competitors (on average) during four years. Tortella and Brusco (2003) discussed the economic adjustments of added value and the efficiency of the company and the market reaction to the amendments in a study. In this study, the economic added value, free cash flows as well as their results showed the market response relationship between economic added value adjustments were important. In addition, added value of economy directly influences the company's free cash flows. Machuga et al. (2002) performed a survey on economic Added value, future profits, financial analysis and forecasting future earnings per share and earnings per share to evaluate the relative effectiveness of EVA as a measure for the value of the shares paid enterprise performance. They showed that economic adjustments added value had some important information about the changes in cash flows and accruals in terms of future profits and revenues. They also found there was a relationship between the wrong predictions and the added value of economical companies.

Irala and Reddy (2005) analyzed the relationship between EVA accounting measures such as earnings per share and capital in US market. Peixoto (2002) studied the relationship between operating profit, net income and EVA in Lisbon, Portugal stock market over the perid 2000-2005. The results of this study showed that compared with operating profit and net profit of the company's market, the value was more correlated. Fernandez (2003) conducted a study to investigate the relationship between the economy and the wealth of added value created for shareholders. The sample included 962 companies and he came to the conclusion that the correlation between the economy and the wealth of added value created for shareholders was only $17 \%$ and 61 companies that have generated positive wealth had negative EVA, 64 were positive companies with a negative wealth created. Finally, he concluded that the economic added value is not able to measure the shareholders' wealth. Eldomiaty (2005) examined the relationship between capital structure and corporate performance of the Egyptian stock exchange. His sample consisted of 22 companies over the period 2007-2011. His capital structure was divided to three levels: companies with high debt, firms with higher, and the ones with lower average debt. In general, there was a strong relationship between short-term and long-term debt with the debt ratio of market value and office value of performance measures and market-related value. 
Ramana (2005) analyzed the relationship between Market value added and EVA in Indian firms and concluded that the net operating profit after tax profit and the interest payments and taxes could be compared. The result showed that the accounting EVA was superior to conventional criteria. Qalibaf Asl (1994) studied the impact of capital structure on the systematic risk of common stock firms listed on the Tehran Stock Exchange and concluded that the use of leverage (debt) could increase the firm systematic risk in stock market. Rahmani (1995) investigated the effect of financing on the stock prices of firms and reported that the issuing new share would cause the increase in stock price and debt would not reduce the stock price without risk. Mojtahedzadeh (1998) investigated the financial restructuring-related benefits and analyzed benefits from the firm's financial restructuring using the results of Stewart and Glassman and concluded that the debt due to tax savings, reducing the likelihood of re-investing excess cash flows, raising incentives for success, selling low-yielding assets and improving performance, productivity and market value will increase. Delavari (1998) studied the impact of funding methods on equity returns of firms listed in Tehran Stock Exchange. Noravesh and Mashayekhi (2004) studied the relationship between operating cash flow, operating income and economic wealth of added value created for shareholders to evaluate EVA, and concluded that it would be a better indicator to predict the wealth created for shareholders. Kavoussi (2004) studied the relationship between Tobin's Q ratio and EVA for some firms on Tehran Stock Exchange and reported that there was a significant relationship between Tobin's Q ratio and economic Added value. Sufiani (2004) examined the relationship between ownership structure and EVA for some firms listed on the Tehran Stock Exchange. He reported that there was a linear relationship between the inverse interest-bearing debt to equity ratio and EVA.

Gholami (2007) determined the relationship between earnings per share and non-metallic mineral products added value financial companies listed on the Stock Exchange done over the period 20002005. He reported there was no significant correlation between the economic and earnings per share added value in terms of effectiveness and economic criteria for examining added value better performance than earnings per share. Mashayekhi et al (2008) studied the usefulness of EVA in anticipated earnings of companies in the period 2002-2007. They stated that there is a significant relationship between changes in earnings and changes in the economic added value in companies. Izadinia and Rahimi Dastjerdi (2008) examined the impact of capital structure on the rate of return on equity and earnings per share listed firms in Tehran Stock Exchange. They showed a direct relationship between debt and equity ratio return on equity and earnings per share there. In addition, a significant correlation between leverage and earnings per share was observed. Taki (2009) examined the relationship between EVA, earnings before interest, tax, cash flows of operating activities providing value in firms listed in Tehran Stock Exchange Companies. The results indicate that earnings before interest and tax of added value had a higher correlation to the market economy. Ghanbari (2010) examined the relationship between EVA and the financial ratios of the companies listed in Tehran Stock Exchange. He concluded that there was a significant relationship between EVA and financial ratios of profitability, liquidity, and efficiency.

\section{Research's Hypotheses}

The main hypotheses: There is a relationship between International Capital Structure and EVA.

\section{Secondary hypotheses:}

(1)There is a relationship between EVA and the ratio of total liabilities and assets in this research.

(2) There is a relationship between the long-term debt and the related economic value of assets.

(3)There is a relationship between EVA and the current debt and assets in this research.

(4)There is a relationship between the EVA and the debt of shareholders in this research.

\section{Research Methodology}

The population of this study consists of firms with the same financial year, other financial intermediaries and investment in the period under review. Out of these companies, 15 companies 
were randomly selected as a pilot sample and the sample variance and the final random sample size was determined as follows:

$$
n=\frac{N \times z_{\alpha / 2}^{2} \times p \times q}{\varepsilon^{2} \times(N-1)+z_{\alpha / 2}^{2} \times p \times q},
$$

where $N$ is the population size, $p=1-q$ represents the yes/no categories, $z_{\alpha / 2}$ is CDF of normal distribution and finally $\varepsilon$ is the error term. Since we have $p=0.5, z_{\alpha / 2}=1.96$ and $N=445$, the number of sample size is calculated as $n=133$. The sample size was approximately 133 and the data was randomly selected for the 133 companies. Financial performance of the companies was studied over a 5 year-period between 2008 and 2012. Since linear regression was used in this study, assumptions of this approach were evaluated. Therefore, to assess the normal distribution of the dependent and independent variables Kolmogorov-Smirnov test was used and for choosing between panel data and mixed data, Lamer F-test was used. The Housman test was used for the detection of differences between fixed and random cross-sectional units, the White test was used to test inequality of variance and to test their independence of errors or lack of correlation between the independent variables Durbin-Watson was used. Linear complex regression was used for the analysis of the complex relationships between variables and to generalize the results to the population of interest in the model parameters and to determine the relationship of t-statistics and F-statistics were used. In this study, the overall relationship between the variables defined in the EVA as the dependent variable and D/A, $\mathrm{LD} / \mathrm{A}, \mathrm{CL} / \mathrm{A}, \mathrm{D} / \mathrm{E}$ as independent variables have been defined as $E V A=f(D / A, L D / A, C L / A, D / E)$ where,

$\mathrm{EVA}=($ Dividends + interest expenses $)$ - (net operating profit after tax),

$\mathrm{D} / \mathrm{A}=$ Total Liabilities divided by the whole assets $=$ Total Assets $/$ Total Liabilities

$\mathrm{LD} / \mathrm{A}=$ long-term debt divided by the whole Assets $=$ Total assets $/$ total debt

$\mathrm{CL} / \mathrm{A}=$ Current liabilities divided by the whole Assets $=$ Total assets / current liabilities

$\mathrm{D} / \mathrm{E}=$ debt to equity ratio $=$ Equity $/$ total debt

Linear relationship between the variables is as follows:

$E V A_{i}=\beta_{0}+\beta_{1} D / A i+\beta_{2} L D / A i+\beta_{3} C L / A i+\beta_{4} D / E i+\varepsilon$

Multiple regression equations using parameters include: $\alpha, \beta_{1}, \beta_{2}, \beta_{3}$ and $\beta_{4}$.

\section{The findings of the study}

In this section, the findings of the analysis are described and then assumptions of complex linear regression are examined and finally the relationships between variables are expressed based on it. In this study, the mean, median, standard deviation, maximum and minimum values of the variable are used to describe the data. Table 1 shows the descriptive variables.

Table 1

Findings description

\begin{tabular}{lcccccc}
\hline Variable & Mean & SD & Max & Min & Skewedness & Kurtosis \\
\hline EVA & 26486 & 745014 & 6675983 & -9346678 & -0.046 & 67.08 \\
Total Assets & 3489106 & 11984838 & 113768199 & 24012 & 6.24 & 45.72 \\
Total Liabilities & 2236159 & 8805021 & 96561034 & 15795 & 7.38 & 63.84 \\
Total Current Liabilities & 2019303 & 8401654 & 93290087 & 9740 & 7.58 & 66.93 \\
Total Long-term Debt & 216856 & 688365 & 9514417 & 0 & 7.23 & 74.43 \\
Total Equity & 1147495 & 270075 & 54085393 & -7409844 & 7.5 & 71.8 \\
Ratio of Total Liabilities to & 0.66 & 0.27 & 2.7 & 0.04 & 2.03 & 13.46 \\
Ratio of current liabilities to & 0.56 & 0.25 & 2.57 & 0.04 & 1.99 & 13.95 \\
Ratio Long-term debt to & 0.06 & 0.13 & 1.37 & 0 & 4.33 & 29.81 \\
\hline Total equity & 1.99 & 4.32 & 41.58 & -53.87 & -2.47 & 56.86 \\
\hline
\end{tabular}

Fig. 1 to Fig. 5 demonstrate the data distribution and related statistical indices: 

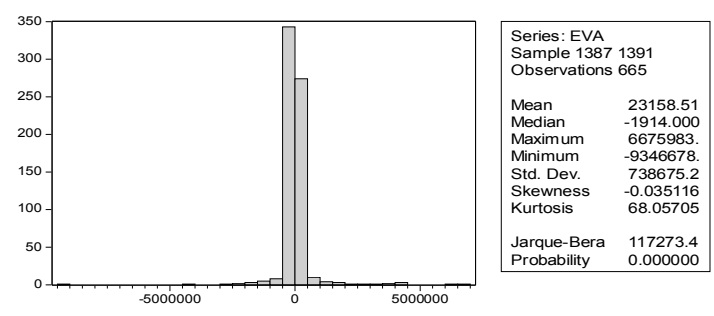

Fig. 1. Distribution of Economic Value Added

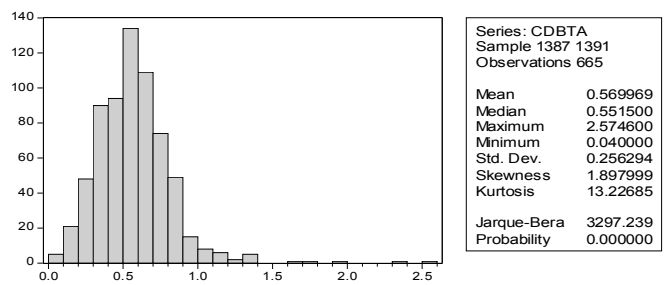

Fig. 3. Distribution of the ratio of current liabilities to total assets
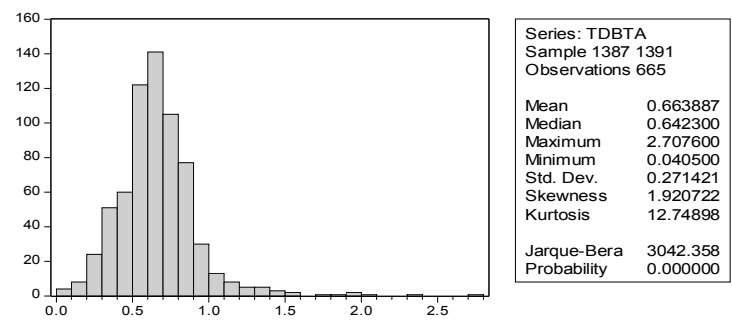

Fig. 2. Distribution of the ratio of total debt to total assets
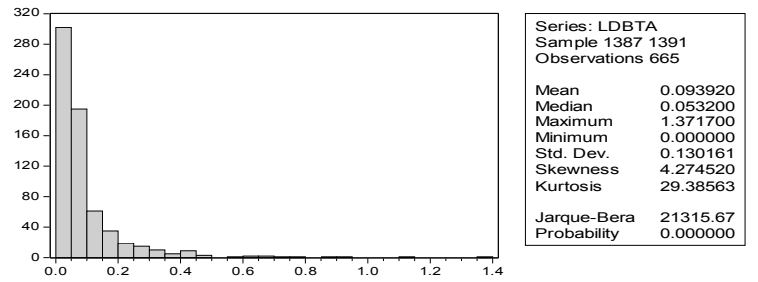

Fig. 4. Histogram of the distribution of long-term debt to total assets ratio

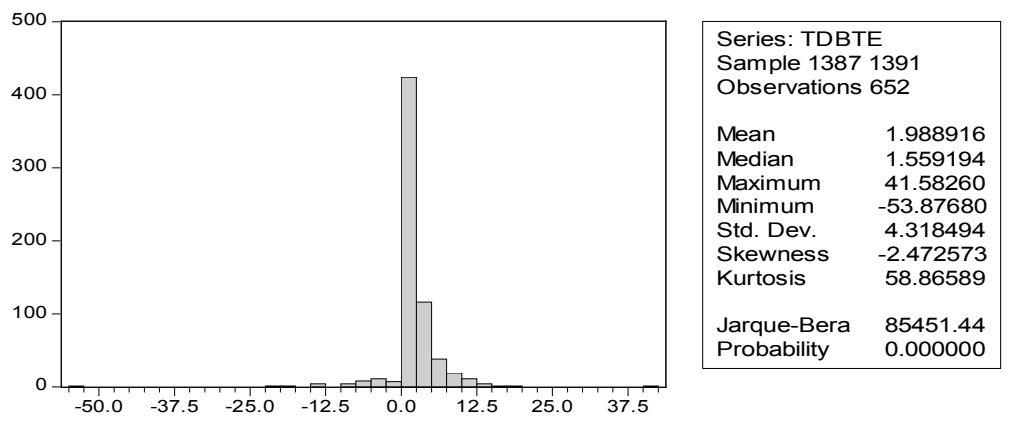

Fig. 5. Distribution of total debt to equity ratio

Like other similar studies, in order to determine the relationship between variables Linear Multiple regression is used. First, the assumptions used in this method have been studied. These assumptions include using DATA Panel methods and assumptions such as the normality of the distribution of the remaining variables, the independent variables are studied, simultaneously.

1) F Lamer Test: To choose between panel data and panel data methods, the $F$ statistics Lamer is used. This hypothesis implies that the intercept equal and opposite hypothesis anisotropy represents the intercept (using panel data). If the calculated p-value is greater than five percent error level, the null hypothesis is not rejected and data integration methods must be used. Otherwise, it will use a panel data approach (Baltagi, 2008). The results of these tests are summarized in Table 2. Based on this table, according to the significance level or probability, which is less than $1 \%$, with $99 \%$ confidence, the null hypothesis is accepted.

2) Housman test: If the null hypothesis is rejected based on the F test Limer, the question remains: They are fixed effects model or random effects methods in which it is done. Hausman test statistic is used to detect fixed or random differences. In Hausman hypotheses are defined based on whether effects are defined or random. If the calculated p-value is greater than five percent error level, the null hypothesis is not rejected and should be used and if the hypothesis is rejected, the random effects method of analysis, the criteria will be shown (Baltaji, 2008). The results of these tests are summarized in Table 2. Since the significance level or probability value in this table is greater than 
$1 \%$ and $5 \%$, with $99 \%$ and $95 \%$ confidence the null hypothesis is rejected that the random effects are accepted.

Table 2

Summary of results of F tests and Housman Lamer

\begin{tabular}{ccccccc}
\hline \multirow{2}{*}{ Description } & \multicolumn{3}{c}{ F Test } & \multicolumn{3}{c}{ Housman test } \\
\cline { 2 - 7 } & statistic & P-Value & result & statistic & P-Value & result \\
\hline Amount & 1.43 & 0.0020 & Data Panel Analysis is suitable & 0.6828 & 0.9534 & Random effects \\
\hline
\end{tabular}

3) Test of independence of errors: in this assumption it is stated that the covariance between the components of disrupt equals zero. Since the graphical methods are unable to detect autocorrelation, we tested the simplest type of test commonly used to diagnose autocorrelation, Durbin-Watson, to calculate association between an error and error before calculating. If the statistics " $\mathrm{d}$ " of the numbers is between 1.5 and 2.5 for the model to be estimated, it indicates the absence of autocorrelation in the model skins. According to the models of Durbin-Watson, the value is equal to 1.75 so assuming autocorrelation of errors in the estimation of the model is rejected.

4) Test for homogeneity of variance: This expression assumes that all errors are equal covariance under the assumption of homogeneity of variance $\sigma^{2}$ is defined in throughput. The panel data could be expected if the degree of homogeneity were more studied periods of time. To check the homogeneity of variance test, LR test is used. If P-Value is less than 5\% significance level, the null of homogeneity of variance is not accepted and the model includes homogeneity between the sections. To resolve the dissonance variance of the generalized least squares (GLS) is used to estimate the pattern. Homogeneity test results are summarized in Table 3:

Table 3

Volatility Test Results

Description

Amount

statistic

$37.47 \quad 0.0000$

Variance anisotropy

Given the significance level or probability of default is almost zero and less than one percent, the variance anisotropy has been rejected. Given the assumption of homogeneity of variance is not established, the generalized least squares method to estimate relationships between variables (GLS) is used.

5) The normal distribution of variables: It is included in the basic assumptions of linear regression, consisting of normal variables. Nonparametric Kolmogorov-Smirnov test was used for this purpose. In this test, the null hypothesis of normally distributed variables is accepted. The results of these tests are summarized in Table 4:

Table 4

Summary of results of Kolmogorov-Smirnov test

\begin{tabular}{ccccc}
\hline Symbol & Variable & parameter & P-Value & result \\
\hline EVA & EVA & 113.25 & 0.0000 & Abnormal \\
D TO A & Liabilities to assets ratio & 98.215 & 0.0000 & Abnormal \\
CD TO A & Current liabilities to assets ratio & 78.251 & 0.0000 & Abnormal \\
LD TO A & Ratio of long term debt to assets & 89.654 & 0.0000 & Abnormal \\
D TO E & Ratio of debt to equity & 95.125 & 0.0000 & Abnormal \\
\hline
\end{tabular}

As shown in Table 4 for all variables the level of significance is near zero. The null hypothesis of non-normal distribution of the dependent and independent variables is rejected. Therefore, we used $\log$ of data squares for data normalization. Then normality test was repeated for converted data and its results showed the converted data distributions are normal.

6) The linear independence of the independent variables: other assumptions rather than the default linear regression are mixed linear independence of the independent variables, the ratio of debt to assets, the ratio of current liabilities to assets ratio, long term debt to assets and debt to equity ratio 
from one another. The default setting for the evaluation of Pearson's correlation analysis was used. The results of this analysis are summarized in Table 5.

Table 5

Analysis of the correlation between variables

\begin{tabular}{lcccc}
\hline Variable & EVA & D/A & LD/A & LD/A \\
\hline EVA & 1 & & & \\
\hline D/A & 0.0000 & & & \\
& 0.08 & 1 & & \\
\hline LD/A & 0.0000 & 0.0000 & 1 & 1 \\
& 0.22 & -0.15 & 0.0000 & 0.0000 \\
\hline LD/A & 0.0000 & 0.06 & 0.037 & 0.0000 \\
\end{tabular}

Table 5 shows the calculation of correlation coefficients of the variables. The linear correlation coefficients are mutually dependent. Diagonal elements of the correlation of each variable with the same variable are equal to a stated purpose. Values of correlation coefficients are close to zero, indicating negligible correlation between the variables. Since the total current liabilities and noncurrent liabilities are equal to the sum of these, variables are highly correlated with the ratio of current liabilities and non-current. In other cases, the correlation coefficients are weak and negligible. The default linear independence of the independent variables on the number of variables is rejected.

7) Establishing a normal distribution of errors: the other default assumption is using the compound the linear regression model. For this cause, the distribution of errors and near zero mean and standard deviation and an almost normal distribution of errors were accepted.

Checking the preliminaries of linear regression compound in the previous section showed that some of these assumptions were not satisfied. For example, none of the variables was normal. In addition, some of the independent variables to the regression coefficient are close to one, linearly independent of each other, they are not established, and no mutual influence of these variables is also demonstrated. With regard to the above forms of research thus combined a mix of linear regression relationships between variables were evaluated and finally the nonparametric analysis has been used:

1) Regression analysis of the variables: Based on similar research, despite the absence of some of the assumptions, linear regression was used to determine the relationship between variables. Based on these parameters, relationships between variables are summarized in Table 6:

Table 6

Estimated Regression Parameters structure

\begin{tabular}{cccccc}
\hline \multicolumn{1}{c}{ Description } & Symbol & coefficient & SD & t & significance \\
\hline Intercept & $\alpha 0$ & 319201 & 144500 & 2.2 & 0.0275 \\
Debt to Assets & D TO A & 1.54 & 2.14 & 0.72 & 0.4712 \\
Current liabilities to assets & CD TO A & -1.35 & 2.14 & -0.72 & 0.4696 \\
Long-term debt to assets & LD TO A & -1.55 & 2.14 & -0.72 & 0.4736 \\
Liabilities to equity & D TO E & -8272 & 10117 & -0.81 & 0.4129 \\
\hline F (probably) & 3.74 & coefficient of determination & 0.02 & \\
Significance level & 0.005 & Durbin-Watson & & 1.75 \\
\hline
\end{tabular}

2) Regression Equation: Based on Table 6 we have,

$\mathrm{EVA}=319201+1.54 \mathrm{D} / \mathrm{A}-1.35 \mathrm{CD} / \mathrm{A}-1.55 \mathrm{LD} / \mathrm{A}-8272 \mathrm{LD} / \mathrm{A}$

3) Variables Relation Analysis: Based on signs of variables in Table 6, the relationships among all variables were analyzed as follows:

a) Results of Table 6 show that the relationship between EVA and the ratio of total debt to assets is direct, but this relationship was not statistically significant. 
b) Results indicate that the relationship between EVA and ratio of current liabilities to total assets, is reversed, but the relationship was not statistically significant.

c) These results suggest that the relationship between EVA and ratio of long term debt to assets is reversed, but this relationship was not statistically significant.

d) The results suggest that the relationship between economic value and debt-to-equity ratio is reversed, but this relationship was not statistically significant.

e) The coefficient of correlation is 0.02 that indicates 0.02 of the changes are due to the relationship between economic value and other variables. In addition, unexplained changes of other variables that are missing from or arising the feasibility of this mathematical relationship may be related to other forms. However, this coefficient is close to zero, which indicates a weak linear relationship between economic value added and capital structure.

4) Fisher-Test Results: Generalized estimating equation based on F-statistics or Fisher test considering the weak linear relationship revealed no significance which cannot be applied to the entire target population and based on the 95 percent there is a poor linear relationship between economic value added and capital structure.

\section{D) Nonparametric analysis:}

As some of the preliminaries to use linear regression showed some of the assumptions of using the compound such as a normal distribution of independent and dependent variables and the independent variables were not established. Spearman nonparametric correlation analysis was used in this section to measure the relationship between economic value added and capital structure ratios. This method examines the relationship of these variables but does not respond to the assumptions approving of compound linear relationship. Spearman nonparametric correlation Table 7 shows the estimates of the analysis. In this table, corresponding to each variable in each high value of correlation coefficient and the bottom number is the level of statistical significance.

Table 7

Analysis of the correlation between variables (Spearman)

\begin{tabular}{|c|c|c|c|c|c|}
\hline & EVA & $\mathrm{D} / \mathrm{A}$ & $\mathrm{LD} / \mathrm{A}$ & $\mathrm{LD} / \mathrm{A}$ & $\mathrm{LD} / \mathrm{A}$ \\
\hline \multirow{2}{*}{ EVA } & 1 & & & & \\
\hline & 0.0000 & & & & \\
\hline \multirow[t]{2}{*}{$\mathrm{D} / \mathrm{A}$} & -0.36 & 1 & & & \\
\hline & 0.0000 & 0.0000 & & & \\
\hline \multirow[t]{2}{*}{$\mathrm{LD} / \mathrm{A}$} & -0.37 & 0.85 & 1 & & \\
\hline & 0.0000 & 0.0000 & 0.0000 & & \\
\hline \multirow[t]{2}{*}{$\mathrm{LD} / \mathrm{A}$} & -0.09 & 0.22 & -0.15 & 1 & \\
\hline & 0.29 & 0.0000 & 0.0000 & 0.0000 & \\
\hline \multirow[t]{2}{*}{$\mathrm{LD} / \mathrm{A}$} & -0.12 & 0.58 & 0.53 & 0.08 & 1 \\
\hline & 00.002 & 0.0000 & 0.0000 & 0.037 & 0.0000 \\
\hline
\end{tabular}

Based on estimates done in the Table 7 the following is summarized:

The correlation between economic value and debt-to-asset ratio of current liabilities to assets ratio, long term debt to assets and debt to equity ratio, respectively, equal to $-0.36,-0.37,-0.09$ and -0.12 significant levels are $0.99,0.99,0.95$ and 0.99 . On this basis: First, because of the negative correlation coefficient between economic value added and each of the above variables, the inverse relationship between economic value and debt-to-asset ratio of current liabilities to assets, long-term debt asset ratio and debt to equity ratio stock existed. Secondly, with regard to the zero coefficient calculated for the relationship between the economic values of long-term debt to equity ratio debt to equity ratio, the relationship between the two is weak. However, the economic value of assets and liabilities to current liabilities to assets ratio is a strong inverse relationship. Third, other than liabilities to assets ratio, compared with the results of regression analysis, the results show roughly 
the same direction. In the second analysis, the inverse relationship between economic value added and capital structure ratios is shown. Finally, almost zero significance level, relatively poor generalization of the inverse relationship between economic value added and capital structure ratios is possible. In other words, in the 99 percent confidence level, there is relatively a weak inverse relationship between economic value added and capital structure.

\section{Conclusion}

This paper has presented an empirical investigation on different factors influencing on EVA. The results show a weak inverse relationship between capital structure and value-added economy. The results are in line with a research conducted by Sufiani (1384) in his dissertation, which examined the relationship between ownership structure and EVA in listed companies in the Tehran Stock Exchange. Analysis of the results of his study shows that there was a linear relationship between the inverse interest-bearing debt to equity ratio and EVA. This result is studied at three levels: integration of industry, non-metallic mineral products industry and building industry machinery and equipment, which did not show the same results (García-Teruel \& Martínez-Solano, 2007). Finally, Sufiani's research suggests that the economy could be an indicator of added value in determining the capital structure of non-metallic mineral products industry attention and generally there was a negative relationship between interest-bearing debt to equity ratio and EVA. According to the results of the Sufiani (1384), the results of the present study were the inverse relationship between the ratio of debt to equity, and EVA. The results of the study are also in line with the results of Shahveisi et al. (2012). Their results showed that the ratio of total debt to assets and economic value were inversely related. The results of this study indicate that there was a negative correlation between the ratio of total debt to assets and the ratio of current liabilities to assets ratio, long term debt to assets and economic value (Biddle et al., 1997).

\section{References}

Biddle, G. C., Bowen, R. M., \& Wallace, J. S. (1997). Does EVA beat earnings? Evidence on associations with stock returns and firm values. Journal of accounting and economics, 24(3), 301336.

Baltagi, B. (2008). Econometric analysis of panel data (Vol. 1). John Wiley \& Sons..

García-Teruel, P. J., \& Martínez-Solano, P. (2007). Effects of working capital management on SME profitability. International Journal of Managerial Finance,3(2), 164-177.

Delavari, J. (1998). Financial effect on equity returns of firms in Tehran Stock Exchange. Accounting Master's Thesis, Tarbiat Modarres University.

de Wet, J. H. (2005). EVA versus traditional accounting measures of performance as drivers of shareholder value-A comparative analysis. Meditari Accountancy Research, 13(2), 1-16.

Eldomiaty, T. I. (2005). What about the Debt Governance Structure and Stockholders' Interests in Transition Market? Perspectives from Egypt.Perspectives from Egypt. Corporate Ownership and Control, 3(2).

Fernandez, P. (2003). EVA, economic profit and cash value added do not measure shareholder value creation. Journal of Applied Finance, 9(3), 74-94.

Ghanbari, A. (2010). The study of the relationship between economic value added and financial ratios of listed companies in Tehran Stock Exchange. Unpublished MA thesis, Tehran University.

Gholami, A. (2007). Exploring the relationship between earnings per share and economic added value of Metal Products Companies listed on the Tehran Stock Exchange. MA Thesis, Imam Khomeini International University.

Hejazi, R., \& Khademi, S. (2013). The impact of firm characteristics and economic factors on the capital structure of listed companies in Tehran Stock Exchange. Financial Accounting Research Journal, 2, 11-16.

Hijazi, R., \& Hosseini, A. (2002). The relationship between economic value added and market value accounting measures in Tehran Stock Exchange. Economic Research, 262-237. 
Irala, D., \& Reddy, L. (2005). EVA: The Right Measure of Managerial Performance?. Indian Journal of Accounting \& Finance, $119(2), 15-36$.

Izadinia, N. (2005).Cash-based accounting standards and proposed performance evaluation measures of economic value added and the free cash flows for the reporting entity's values. Journal of Administrative Sciences and Economics, University of Isfahan, 36.

Izadinia, N., \& Rahimi dastjerdi, M. (2008). The effect of capital structure on the rate of return on equity and earnings per share of listed companies in Tehran Stock Exchange. Accounting Research, 1 (3), 161-136.

Kavoussi, A.R. (2004). Relationship between Tobin's Q ratio and economic added value in evaluating the performance of the company. MA Thesis, Isfahan University.

Kleiman, R. T. (1999). Some new evidence on EVA companies. Journal of Applied Corporate Finance, 12(2), 80-91.

Machuga, S. M., Pfeiffer Jr, R. J., \& Verma, K. (2002). Economic value added, future accounting earnings, and financial analysts' earnings per share forecasts.Review of Quantitative Finance and Accounting, 18(1), 59-73.

Mashayekhi, B. et al. (2008). EVA usefulness in predicting earnings. Journal of Financial Accountants, 4, 71-89.

Modigliani, F., \& Miller, M. H. (1963). Corporate income taxes and the cost of capital: a correction. The American Economic Review, 53, 433-443.

Mojtahedzadeh, V. (1998). The financial benefits of restructuring. Accounting Monthly, 126, 37-31.

Nikbakht, M.R., \& Peikani, M. (2010). The relationship between capital structure and performance assessment of accounting standards. Financial Research, 11(28), 104-89.

Noravesh, I., \& Mashayekhi, B. (2004). Economic value added benefit in increasing the earnings of companies listed in Tehran Stock Exchange. Accounting and Audit Reviews, 95-108

O'Byrne, S. F. (1996). EVA ${ }^{\circledR}$ and market value. Journal of Applied Corporate Finance, 9(1), 116126.

Peixoto, S. M. (2002). Economic Value Added (R)-Application to Portuguese Public Companies. Available at SSRN 302687.

Qalibaf Asl, H. (1994). The effect of capital structure on the systematic risk. MS Thesis Commercial Management, Tehran University.

Rahmani, M. (1995). The impact of finance on the stock price. Master Thesis Management, Tehran University.

Ramana, D. V. (2005). Market value added and economic value added: Some empirical evidences. Bhuabneswar, Mumbai, 3(8), 1-15.

Shahveisi, F., Navid, B. J., Najafi, Y., \& Hosseini, S. A. A. (2012). The Study of the Relationship between the Capital Structure and the Variables of the Value-based Performance Assessment. Research Journal of Finance and Accounting,3(7), 131-139.

Stewart, G.B. III. (1991). The Quest for Value. New York: Harper-Collins.

Stewart. G., (1995). EVA: fact or fantasy. Journal of Applied Corporate Finance, 71-84.

Sufiani, A. (2004). The relationship between ownership structure and economic value added. Accounting Unpublished MA thesis, University of Tehran, Tehran.

Taki, A. (2009). Investigation of the relationship between economic value added, interest and taxes and cash flow from operating activities Market. Quarterly Journal of Financial Accountants, University of Isfahan, 5, 120-139.

Tortella, B. D., \& Brusco, S. (2003). The Economic Value Added (EVA): an analysis of market reaction. Advances in Accounting, 20, 265-290.

Zaima, J. K., Turetsky, H. F., \& Cochran, B. (2005). The MVA-EVA relationship: Separation of market driven versus firm driven effects. Review of Accounting and Finance, 4(1), 32-49. 